\title{
Estimating Transpiration of Whole Grapevines under Field Conditions
}

\author{
P.A. Myburgh \\ ARC Infruitec-Nietvoorbij ${ }^{1}$, Private Bag X5026, 7599, Stellenbosch, South Africa
}

Submitted for publication: October 2015

Accepted for publication: April 2016

Key words: Canopy orientation, $\mathrm{ET}_{\mathrm{o}}$, heat pulse, leaf area, sap flow

\begin{abstract}
The accurate estimation of vineyard water use is important for irrigation scheduling in order to optimise yield, growth and quality. Diurnal whole-plant transpiration, to be used in combination with a soil evaporation model to estimate vineyard evapotranspiration, was quantified by measuring sap flow in grapevines. Sap flow was measured in grapevine trunks by means of the heat pulse velocity technique. Diurnal sap flow ranged from almost zero to $c$. $5 \mathrm{~L} / \mathrm{d}$ per grapevine under various atmospheric, viticultural and soil conditions. Sap flow showed good linear correlation with leaf area per grapevine and reference evapotranspiration (ET). Grapevines with similar leaf area trained onto horizontally orientated trellis systems transpired more than those on vertical trellises under the same atmospheric conditions. Approximately $90 \%$ of the variation in daily transpiration could be explained by means of multiple linear regression, with leaf area and daily $\mathrm{ET}_{0}$ as the independent variables. However, grapevines with horizontal and vertical canopies required slightly different models.
\end{abstract}

\section{INTRODUCTION}

In South Africa, most vineyards need irrigation for sustainable growth, yield and product quality, except for some rain-fed vineyards in the Coastal region of the Western Cape province. Therefore, accurate estimation of a vineyard's water requirements is essential for irrigation scheduling. Evapotranspiration of vineyards $\left(\mathrm{ET}_{\mathrm{c}}\right)$ is generally considered as a single process that integrates evaporation from the soil surface and transpiration by grapevines. Crop coefficients $\left(\mathrm{K}_{\mathrm{c}}\right)$ and a reference evaporation rate $\left(\mathrm{ET}_{\mathrm{o}}\right)$ can be used to estimate $\mathrm{ET}_{\mathrm{c}}$ as follows (Allen et al., 1998):

$\mathrm{ET}_{\mathrm{c}}=\mathrm{K}_{\mathrm{c}} \times \mathrm{ET}_{\mathrm{o}}$

In South Africa, two sets of $\mathrm{K}_{\mathrm{c}}$ values are recommended for the supplementary and intensive irrigation of wine grapes, as well as a third set for table grapes (Green, 1985). However, studies have shown that $\mathrm{ET}_{\mathrm{c}}$ and $\mathrm{K}_{\mathrm{c}}$ can vary considerably between vineyards in South Africa. The variation in $\mathrm{ET}_{\mathrm{c}}$ is due to aspects such as differences in growth vigour induced by root depth (Myburgh et al., 1996), level of soil water depletion before irrigation is applied (Fourie, 1989; Myburgh, 2003b; Myburgh \& Howell, 2007a) and irrigation system (Myburgh, 2003a; Myburgh, 2012). These studies showed that $K_{c}$ varied primarily due to differences in leaf area per grapevine and/or differences in evaporation losses $\left(\mathrm{E}_{\mathrm{s}}\right)$ where only a fraction of the soil was wetted or irrigation frequency varied. It was also shown that soil type, atmospheric conditions and canopy orientation have pronounced effects on $\mathrm{E}_{\mathrm{s}}$ in vineyards (Myburgh, 2015). Given the high $\mathrm{E}_{\mathrm{s}}$ rates following irrigation or rainfall (Myburgh, 2013), $\mathrm{E}_{\mathrm{s}}$ may constitute a substantial fraction of $\mathrm{ET}_{c}$, particularly if irrigation is applied frequently. In fact, $\mathrm{E}_{\mathrm{s}}$ could amount to $20 \%$ of $\mathrm{ET}_{\mathrm{c}}$ in drip-irrigated vineyards (Poblete-Echeverría \& Ortega-Farias, 2013). In order to improve $\mathrm{ET}_{\mathrm{c}}$ estimations, the single crop coefficient, $\mathrm{K}_{\mathrm{c}}$, is separated into a basal crop coefficient $\left(\mathrm{K}_{\mathrm{cb}}\right)$ and a soil evaporation coefficient $\left(\mathrm{K}_{\mathrm{e}}\right)$ (Allen et al., 1998). According to this dual crop coefficient approach, $\mathrm{ET}_{\mathrm{c}}$ is calculated as follows:

$\mathrm{ET}_{\mathrm{c}}=\left(\mathrm{K}_{\mathrm{cb}}+\mathrm{K}_{\mathrm{e}}\right) \times \mathrm{ET}_{\mathrm{o}}$

Based on the foregoing, it is essential that transpiration and $\mathrm{E}_{\mathrm{s}}$ should be quantified separately in order to understand how atmospheric conditions, soils and viticultural practices affect vineyard water requirements.

Grapevine transpiration responds to atmospheric variables such as ambient air temperature, global radiation and vapour pressure deficit, as well as viticultural conditions, particularly soil water status (Düring, 1976; Loveys \& Düring, 1984; Van Zyl, 1987; Winkel \& Rambal, 1990; Beis \& Patakas, 2010, Zhang et al., 2011; Rogiers et al., 2012). However, transpiration per unit leaf area, and stomatal

\footnotetext{
${ }^{1}$ The Fruit, Vine and Wine Institute of the Agricultural Research Council

*Corresponding author: E-mail address: myburghp@arc.agric.za

Acknowledgements: The ARC is thanked for infrastructure and other resources, Winetech for partial funding of the research, and the Soil and Water Science staff at the ARC Infruitec-Nietvoorbij for technical support
} 
conductance or resistance provide only an indication of stomatal responses to variables such as atmospheric conditions and soil water availability at the leaf level. Therefore, whole-plant transpiration needs to be determined in order to quantify the transpiration losses of vineyards. Techniques such as heat pulse velocity sensors (Swanson \& Whitfield, 1981; Poblete-Echeverría et al., 2012), stem heat balance sensors (Baker \& Van Bavel, 1987; Escalona et al., 2000; Zhang et al., 2011), Granier-type sensors (Braun \& Schmid, 1999; Lopes et al., 2004) and dual heat pulse sensors (Pearsall et al., 2014) have made it possible to quantify the daily sap flow of whole plants. A further advantage of these measurements is that continuous sap flow recording provides an almost complete quantification of the transpiration component of ET. Consequently, sap flow techniques have been widely adopted to quantify whole-plant transpiration of grapevines in pots (Braun \& Schmid, 1999; Escalona et al., 2002), in the open field (Lascano et al., 1992; Schmid, 1997; Eastham \& Gray, 1998; Ginestar et al., 1998; Lopes et al., 2004; Patakas et al., 2005; Myburgh \& Howell, 2006; McClymont et al., 2009; Poblete-Echeverría et al., 2012) and in a weighing lysimeter (Pearsall et al., 2014).

Seasonal variation in grapevine sap flow is related to changes in leaf area (Zhang et al., 2011). Previously reported maximum whole-plant daily sap flow for grapevines varied substantially (Table 1). Although not determined directly by sap flow measurements, but rather by means of weighing lysimeters, daily water use of well-watered Thompson Seedless grapevines could be as high as $40 \mathrm{~L} /$ grapevine under conditions of high evaporative demand (Williams et al., 2011). Being so closely related to transpiration, the amount of daily sap flow is subject to variation in atmospheric conditions or evaporative demand (Schmid, 1997; Eastham \& Gray, 1998; Calo et al., 1999; Escalona et al., 2002; Patakas et al., 2005). Canopy characteristics also affect diurnal sap flow in grapevines. As expected, whole-plant sap flow increases with increasing leaf area per grapevine (Schmid, 1997; Eastham \& Gray, 1998; Zhang et al., 2011). Diurnal sap flow in grapevines trained onto the upper wire of a two-tier vertical trellis was higher compared to the less exposed ones on the lower wire (Ginestar et al., 1998). It was also shown that sap flow in grapevines with downward-oriented shoots is lower compared to grapevines with upward-oriented shoots (Calo et al., 1999). Grapevine sap flow is reduced by decreasing soil water availability (Eastham \& Gray, 1998; Ginestar et al., 1998; De Lorenzi \& Rana, 2000; Escalona et al., 2002; De Souza et al., 2003; Patakas et al., 2005; Myburgh \& Howell, 2006; Fernández et al., 2008; McClymont et al., 2009; Zhang et al., 2011). These sap flow reductions were either induced directly where insufficient soil water was available for absorption, or indirectly where grapevine leaf area was reduced due to prolonged water deficits.

It was previously shown that sap flow followed fluctuations, or spikes, in net radiation during daytime (Fernández et al., 2008). In contrast, sap flow may also fluctuate under seemingly stable atmospheric conditions (Eastham \& Gray, 1998; Braun \& Schmid, 1999; De Lorenzi \& Rana, 2000; Patakas et al., 2005; Myburgh \& Howell, 2006; Poblete-Echeverría et al., 2012). There are no apparent explanations for these fluctuations. However, daytime sap flow fluctuations seems to be induced when transpiration exceeds water uptake, resulting in a period of temporarily reduced transpiration (Myburgh \& Howell, 2006). During this period, continued water flow from the surrounding soil towards the root-soil interface probably reduces the water potential gradient, followed by increased water uptake and transpiration. The temporary fluctuations in sap flow seem to occur more frequently as the soil water content decreases (Myburgh \& Howell, 2006).

The objectives of this study were (i) to determine the effects of viticultural and atmospheric conditions on diurnal sap flow in field-grown grapevines and (ii) to develop a model for estimating daily transpiration at the whole-plant level.

\section{MATERIALS AND METHODS \\ Sap flow experiments}

Effects of leaf area, canopy surface area orientation, leaf removal and irrigation on sap flow were determined in a series of experiments in different vineyards. The vineyards represented different soil types, scion cultivars, trellis systems and grapevine plant spacing typical of various South African grape-growing regions.

TABLE 1

Maximum daily sap flow rate in grapevines recorded in different studies.

\begin{tabular}{|c|c|c|c|}
\hline Cultivar & Sap flow (L/grapevine/d) & Sap flow method & Source \\
\hline Cabernet Sauvignon & 6.7 & Heat balance & Lascano et al. (1992) \\
\hline Various & $5.1-7.5$ & Heat pulse & Eastham \& Gray (1998) \\
\hline Shiraz & 4 & Heat pulse & Ginestar et al. (1998a) \\
\hline Weisser Riesling & 5 & Granier & Braun \& Schmid (1999) \\
\hline Weisser Riesling & 2 & Granier & Lopes et al. (2004) \\
\hline Cabernet Sauvignon & 7 & Tmax heat pulse & Fernández et al. (2008) \\
\hline Shiraz & 13 & Tmax heat pulse & McClymont et al. (2009) \\
\hline Merlot $^{(1)}$ & 1.6 & Heat balance & Zhang et al. (2011) \\
\hline Merlot & 10 & Heat pulse & Poblete-Echeverría et al. (2012) \\
\hline
\end{tabular}

(1) Sap flow measured per half grapevine. 


\section{Experiment 1}

The effect of leaf area on sap flow early in the season was determined in a sixteen-year-old, flood-irrigated, ownrooted Sultanina vineyard in the lower Orange River region of the Northern Cape province. This locality is at $28^{\circ} 27^{\prime}$ $\mathrm{S}$ latitude and, based on the growing degree days (GDD) from September until March (Winkler, 1962), it is a Class $\mathrm{V}$ region for viticulture (Le Roux, 1974). Grapevines were planted $3 \mathrm{~m} \times 1.5 \mathrm{~m}$ in alluvial soil belonging to the Dundee form (Soil Classification Work Group, 1991). Grapevines were trained onto a $2.4 \mathrm{~m}$ slanting trellis (Avenant, 1990) and cane pruned, allowing 12 to 18 nodes per cane. Sap flow was measured in three grapevines with comparable trunk diameter, canopy size and crop load. Fourteen days prior to the measurements, c. $30 \%$ and $60 \%$ of the shoots were removed evenly around the crown from two of these grapevines respectively. The vineyard was irrigated every 14 days. Sap flow measurements commenced one week after an irrigation, and were carried out from 1994-10-08 until 1994-10-11, i.e. just before flowering.

\section{Experiment 2}

The purpose of this experiment was to determine the effect of leaf area on sap flow during berry development. The experiment was carried out on the De Doorns research farm of the Agricultural Research Council (ARC) in the Hex River Valley of the Western Cape province. This locality is at $33^{\circ} 28^{\prime} \mathrm{S}$ latitude in a Class IV region for viticulture (Le Roux, 1974). The sixteen-year-old Barlinka grapevines grafted onto Ramsey were planted $3 \mathrm{~m} \mathrm{x} 1.5 \mathrm{~m}$ in a sandy soil belonging to the Fernwood form (Soil Classification Work Group, 1991). Grapevines were trained onto a $2.4 \mathrm{~m}$ slanting trellis (Avenant, 1990). Sap flow was measured in three grapevines naturally varying in canopy size, i.e. no canopy manipulations were carried out. The vineyard was irrigated weekly by means of micro-sprinklers. Sap flow measurements commenced two days after an irrigation was applied, and were carried out from 1994-12-01 until 1994-12-05.

\section{Experiment 3}

The purpose of this experiment was to quantify sap flow in a grapevine with a small canopy. Measurements were carried out on a three-year-old 99 Richter rootstock growing in a $15 \mathrm{dm}^{3}$ pot. The soil surface was sealed using domestic candle wax to minimise evaporation losses. Six $5 \mathrm{~mm} \varnothing$ holes were drilled in the c. $3 \mathrm{~mm}$ thick wax layer to allow irrigation. The grapevine was placed in an open field next to a commercial Pinot noir vineyard on the Nietvoorbij research farm of the ARC near Stellenbosch. This locality is at $33^{\circ} 54^{\prime} \mathrm{S}$ latitude in the Coastal region of the Western Cape province, and is considered to be a Class III region for viticulture (Le Roux, 1974). The potted grapevine was watered weekly by hand. Sap flow was measured from 1994-12-26 until 1994-12-29. The grapevine was watered one day before the sap flow measurements commenced, and was weighed daily to determine transpiration losses.

\section{Experiment 4}

This experiment was carried out to quantify sap flow in grapevines with vertically orientated canopies. Sap flow was measured in eight-year-old Pinot noir grapevines grafted onto 99 Richter at the same locality as Experiment 3. Grapevines were planted $2.75 \mathrm{~m} \times 1.5 \mathrm{~m}$ in a granitic soil belonging the Glenrosa form (Soil Classification Work Group, 1991). Grapevines were trained onto a fivestrand lengthened Perold trellis (Booysen et al., 1992). The vineyard was irrigated weekly by means of micro-sprinklers. This particular experiment consisted of two parts. In the first part, sap flow was measured in two grapevines planted in soil that was prepared to $40 \mathrm{~cm}$ and $120 \mathrm{~cm}$ depths respectively, as part of a soil preparation experiment (Myburgh et al., 1996). Measurements were carried out from 1994-12-30 until 1995-01-08, i.e. during berry development. The second part was carried out to determine if the measurements were repeatable. Sap flow was measured in two different grapevines with canopies that were visually comparable to the canopy of the grapevine in the deeply prepared soil. These measurements were carried out from 1995-01-12 until 1995-01-20.

\section{Experiment 5}

Leaf area effects on sap flow during berry ripening were determined in the same flood-irrigated Sultanina vineyard near Upington in which Experiment 1 was carried out. Sap flow was measured in three grapevines naturally differing in canopy size. The grapevines were not the same as the ones used in Experiment 1. Sap flow measurements were carried out shortly before harvest, from 1995-01-22 until 1995-01-27.

\section{Experiment 6}

The purpose of this experiment was to determine the effect of canopy surface orientation on diurnal sap flow. The experiment was carried out in a trellis systems trial on the Robertson research farm of the ARC in the Breede River Valley of the Western Cape province. This locality is at $30^{\circ} 50^{\prime} \mathrm{S}$ latitude in a Class IV region for viticulture (Le Roux, 1974). The seven-year-old Emerald Riesling grapevines were grafted onto 110 Richter and planted $3 \mathrm{~m} \mathrm{x} 1.5 \mathrm{~m}$ in a sandy clay loam soil belonging to the Garies form (Soil Classification Work Group, 1991). Sap flow was measured in two grapevines with comparable trunk diameters. One grapevine was trained onto a vertical five-strand hedge (Booysen et al., 1992), and the other onto a $1.8 \mathrm{~m}$ slanting trellis (Avenant, 1990). The grapevines were irrigated weekly by means of micro-sprinklers, but no irrigation was applied during the final stage of berry ripening, when measurements were carried out from 1995-02-08 until 1995-02-11.

\section{Experiment 7}

The purpose of this experiment was to quantify sap flow in a grapevine with a large vertically orientated canopy. Sap flow was measured in a seven-year-old Emerald Riesling grapevine that was grafted onto 110 Richter in the same trellis systems field trial in which Experiment 6 was carried out. The grapevine was trained onto a $4.2 \mathrm{~m}$ Tatura trellis (Van den Ende, 1994). The plant spacing was $4.2 \mathrm{~m}$ x $1.5 \mathrm{~m}$. 
Sap flow measurements were carried out during the postharvest period, from 1995-04-04 to 1995-04-08.

\section{Measurements}

The heat pulse velocity technique was used to measure sap flow in the grapevine trunks. Since sap flow velocities vary with radial depth (Escalona \& Ribas-Carbó, 2010; PobleteEcheverría et al., 2012), four sets of thermistor probes and heaters were installed in the xylem at different depths as described by Myburgh (1998). Sap flow was recorded at 15-minute intervals using a heat pulse-generation, temperature-sensing and data-logging system (Micro Innovations, Pretoria). Mean hourly sap flow was calculated. Trunk cross-sectional area was measured as described by Myburgh and Coetzee (2004) at all positions where heaters were installed. Heat pulse propagation time (seconds) was converted to hourly sap flow (mL/grapevine/h) using trunk cross-sectional area and the empirical calibration curves determined earlier (Myburgh, 1998). Hourly sap flow was summed from midnight to midnight and divided by $10^{3}$ to obtain diurnal sap flow (L/grapevine/d). Upon completion of each experiment, all leaves were removed from the grapevine(s) in which sap flow had been measured. In Experiments 4 and 7, sap flow measurements continued for c. six hours after leaf removal. Total leaf area per grapevine was determined using an electronic leaf area meter (LI3100, Li-Cor, Nebraska). Daily transpiration per grapevine was calculated as follows:

$\mathrm{T}=\mathrm{Q} / \mathrm{A}$

where $T$ is transpiration $(\mathrm{mm} / \mathrm{d}), \mathrm{Q}$ is sap flow $(\mathrm{L} / \mathrm{d})$ and $A$ is area allocated per grapevine $\left(\mathrm{m}^{2}\right)$. Hourly weather data and ET were obtained from the ARC Institute for Soil, Climate and Water (ISCW) in Pretoria. All sap flow experiments were carried out within $1 \mathrm{~km}$ from a weather station. Since weather data was incomplete when Experiments 1 and 6 were carried out, ET could not be calculated. The $\mathrm{K}_{\mathrm{cb}}$ was calculated as follows:

$\mathrm{K}_{\mathrm{cb}}=\mathrm{T} / \mathrm{ET}_{\mathrm{o}}$

Grapevine water status was only determined when Experiments 1 and 2 were carried out. Midday leaf water potential $\left(\Psi_{L}\right)$ was measured in mature leaves fully exposed to the sun by means of the pressure chamber technique (Scholander et al., 1965). To minimise possible effects of reduced leaf area on sap flow per grapevine, $\Psi_{\mathrm{L}}$ was measured in only two leaves on primary shoots per grapevine.

\section{Statistical analyses}

Since the primary objective of the study was to obtain a range of diurnal sap flow values, it was not regarded as a comparative study. Therefore, there were no treatment replications. Linear and multiple linear regressions were calculated using STATGRAPHICS ${ }^{\circledR}$ version XV (StatPoint Technologies, Warrenton, Virginia, USA).

\section{RESULTS AND DISCUSSION}

\section{Factors affecting sap flow}

Leaf area per grapevine

Total leaf area per grapevine varied between $0.17 \mathrm{~m}^{2}$ for the potted 99 Richter rootstock (Experiment 3) and $14.2 \mathrm{~m}^{2}$ for the Emerald Riesling grapevine on the Tatura trellis system (Experiment 7). As expected, diurnal sap flow per grapevine was strongly affected by leaf area. Diurnal sap flow of the Barlinka grapevines in Experiment 2 clearly increased with increasing leaf area per grapevine (Fig. 1). Mean midday $\Psi_{L}$ was $-1.22 \pm 0.14 \mathrm{MPa}$, which indicated that the grapevines experienced mild to moderate water constraints, i.e. between -1.2 and -1.4 MPa (Myburgh, 2011a and references therein). Sap flow of the Pinot noir grapevine was also higher where deeper soil preparation induced higher leaf area per grapevine

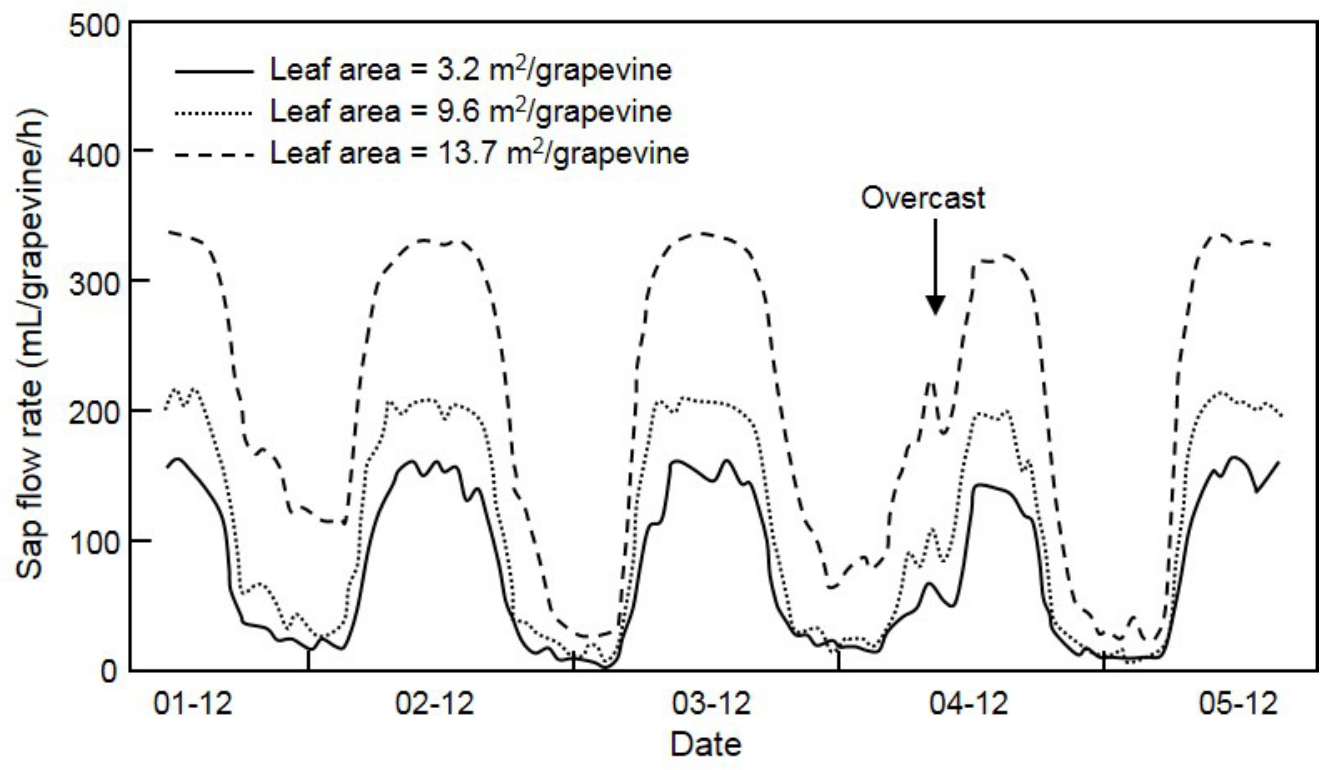

FIGURE 1

Effect of leaf area on sap flow in three Barlinka grapevines on a $2.4 \mathrm{~m}$ slanting trellis as measured near De Doorns during phase two of berry development from 1994-12-01 to 1994-12-05. 


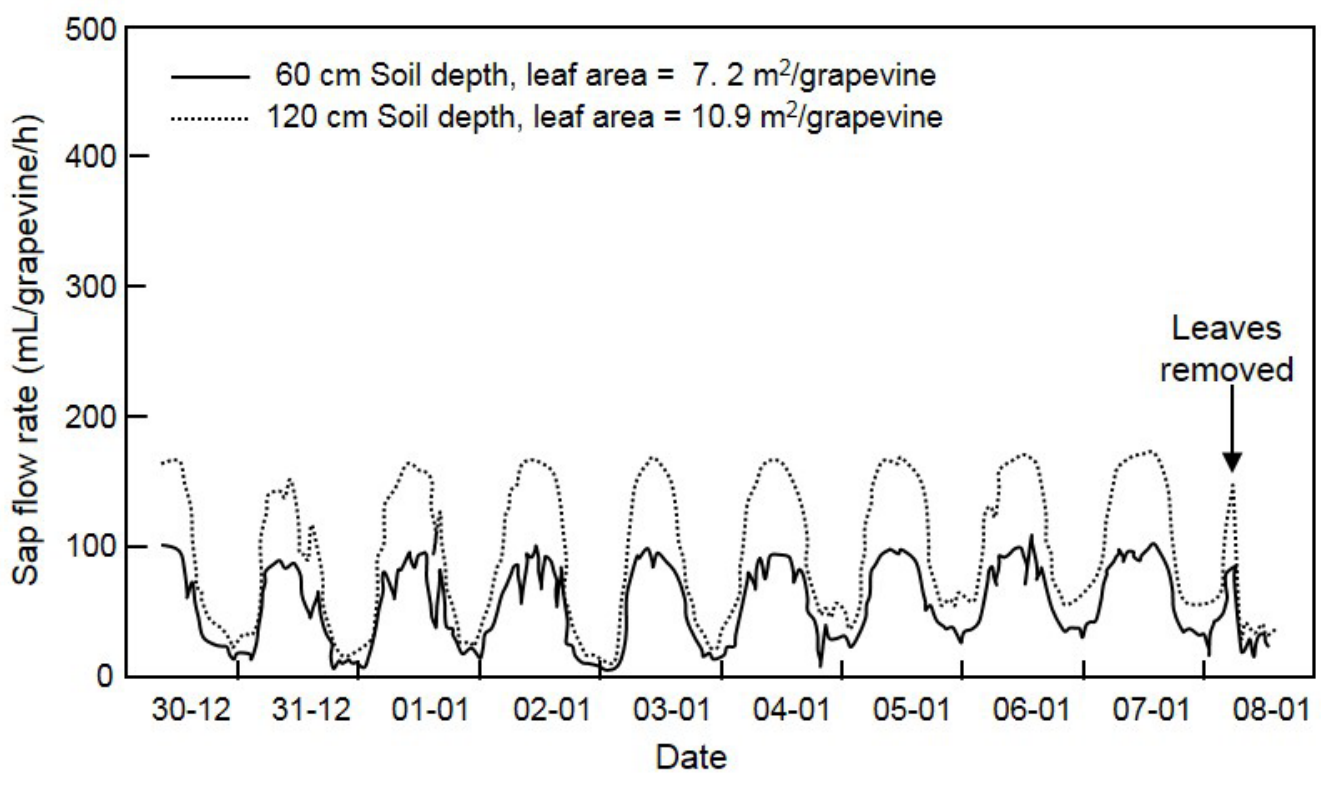

FIGURE 2

Effect of leaf area per grapevine, as induced by soil preparation depth, on sap flow rate in two Pinot noir grapevines on a lengthened Perold trellis as measured near Stellenbosch during phase three of berry development from 1994-12-30 to 1995-01-08.

compared to the grapevine with a smaller leaf area in the shallower soil in Experiment 4 (Fig. 2). It was previously reported that irrigated Pinot noir grapevines in the same vineyard experienced mild to moderate water constraints (Myburgh et al., 1996). The increasing diurnal sap flow per grapevine with increasing leaf area was in agreement with earlier findings (Schmid, 1997; Eastham \& Gray, 1998; Zhang et al., 2011).

Although the daytime fluctuations seem to have masked the effect of leaf area on sap flow in the Sultanina grapevines used in Experiment 1 (Fig. 3A), cumulative sap flow clearly increased with increasing leaf area (Fig. 3B). Since mean midday $\Psi_{\mathrm{L}}$ was $-0.97 \pm 0.11 \mathrm{MPa}$, the grapevines experienced no water constraints, i.e. $\Psi_{\mathrm{L}}$ was higher than $-1 \mathrm{MPa}$ (Myburgh, 2011a and references therein). Therefore, it was unlikely that soil water deficits could have induced partial stomatal closure early in the growing season. Furthermore, sap flow fluctuations occurred irrespective of shoot removal prior to the sap flow measurements, which indicates that canopy manipulation did not disturb physiological functioning. The foregoing suggests that the fluctuations during daytime were probably induced by temporary water deficits at the rootsoil interface (Myburgh \& Howell, 2006). Daytime sap flow fluctuations also occurred in Sultanina grapevines later in the growing season, when Experiment 5 was carried out (Fig. 4). It was previously shown that irrigation applied at two- to three-week intervals induced strong water deficits, viz. $\Psi_{\mathrm{L}}$ c. $-1.6 \mathrm{MPa}$, in the same Sultanina vineyard during berry ripening (Myburgh, 2003a). Therefore, soil water deficits could have contributed to the fluctuating sap flow via partial stomatal closure. Following total leaf removal during the day in Experiment 4, sap flow of the Pinot noir grapevine declined rapidly to almost zero (Fig. 2). Sap flow in the Emerald Riesling grapevine on the Tatura trellis system responded similarly when leaves were removed (Fig. 5). The rapid decline upon leaf removal confirmed the substantial contribution of transpiration to whole grapevine sap flow.

Night-time sap flow rates were substantially lower than daytime flow rates (Figs 1, 2, 4 \& 5). The observed low levels of night-time sap flow were in agreement with earlier findings (Eastham \& Gray, 1998; Myburgh \& Howell, 2006; Fuentes et al., 2009; McClymont et al., 2009; PobleteEcheverría et al., 2012). The night-time sap flow seems to be related to grapevine trunk expansion in the night, when plant water status recovers, followed by contraction during the day, when transpiration exceeds water uptake (Myburgh, 1996; Escalona et al., 2002). The replenishment of water deficits, which takes place during the day when transpiration exceeds water uptake from the soil, is considered to be the primary reason for sap flow during the night (Fernández et al., 2008; Fuentes et al., 2014). Night-time sap flow tended to increase with increasing leaf area per grapevine (Figs. 1, $2 \& 4$ ). This indicates that increasing canopy size increased the volume of water required to replenish daytime deficits. Furthermore, it was previously shown that water potential gradients in grapevines cause water flow from the bunches to the leaves during day time, and from the soil to the bunches at night (Van Zyl, 1987). Therefore, the replenishment of bunch water status could also have contributed to nocturnal sap flow. The latter probably explains why almost no nocturnal sap flow occurred in the Emerald Riesling on the large Tatura trellis in the post-harvest period in Experiment 7 (Fig. 5). However, the foregoing does not rule out the possibility that limited transpiration (Escalona et al., 2013; Rogiers \& Clarke, 2013) contributed to nocturnal sap flow.

\section{Canopy orientation}

The perusal of the sap flow data of the Emerald Riesling 

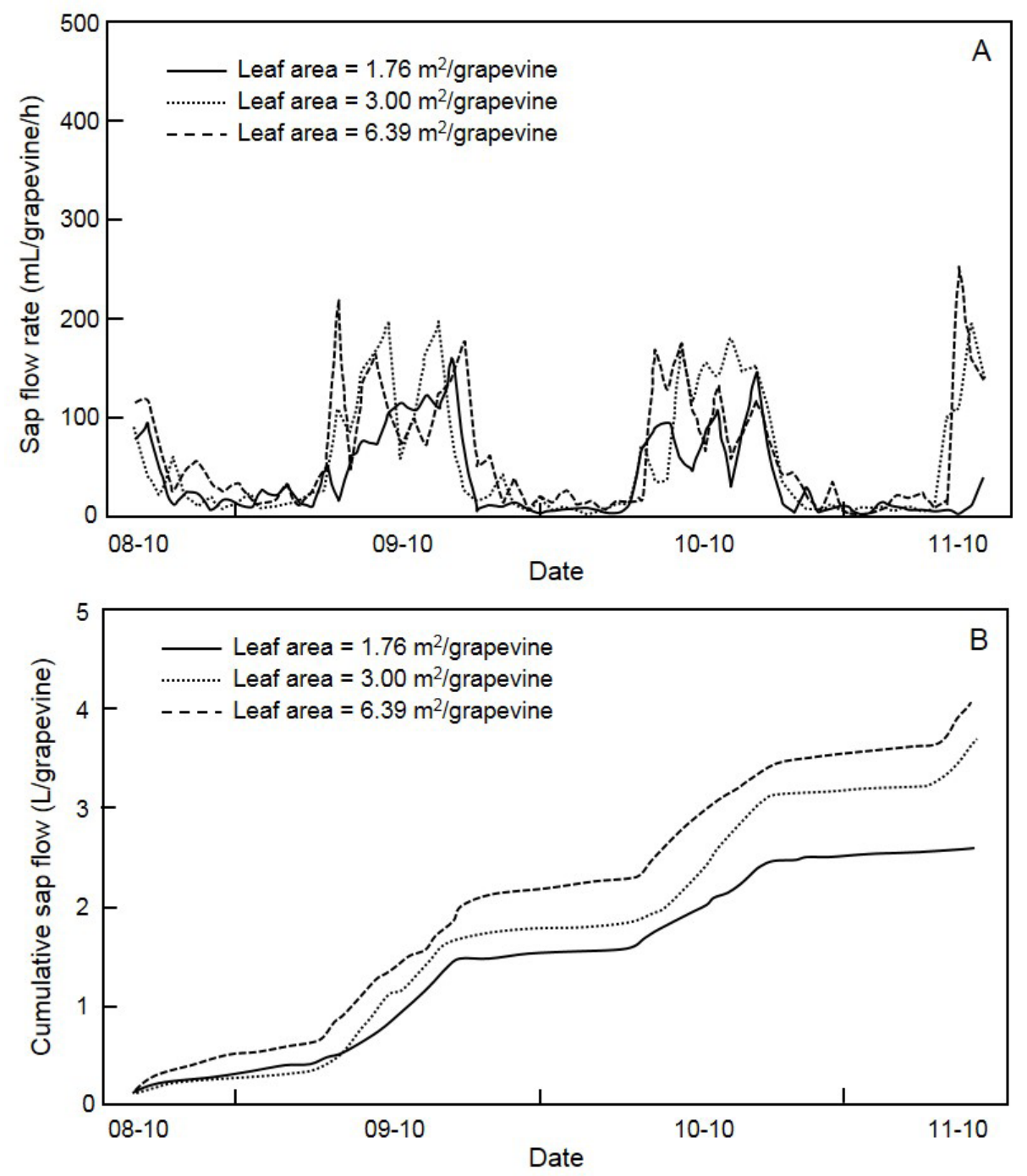

FIGURE 3

Effect of leaf area per grapevine on (A) diurnal sap flow rate and (B) cumulative sap flow in three Sultanina grapevines on a 2.4 m slanting trellis, as measured near Upington prior to flowering from 1994-10-08 until 1994-10-11.

grapevine on the vertical trellis revealed that only two of the four thermistor probes functioned properly when Experiment 6 was being carried out (data not shown). The malfunctioning probes were the shallowest ones, i.e. in the youngest xylem, where sap flow is usually higher than closer to the pith (Myburgh, 1998; Poblete-Echeverría et al., 2012). Since these measurements would over-estimate the sap flow, the data of the grapevine on the vertical trellis were discarded for the purpose of the study. Consequently, the effect of canopy system orientation could not be determined in the same scion cultivar/rootstock combination under the same conditions. However, sap flow measured in grapevines with horizontally orientated canopies was generally higher than in grapevines with vertically orientated canopies with comparable leaf area (Fig. 6). Although the canopies of grapevines on the Tatura trellis formed a $60^{\circ}$ angle with the soil surface, diurnal sap flow of the grapevine measured in Experiment 7 was in line with that of other grapevines having smaller leaf areas on vertical trellises (Fig. 6).

It must be noted that sap flow is regarded as the integrated transpiration of all the leaves in the canopy. The fact that the physiological functioning of leaves that are fully exposed to the sun differs from shaded leaves is well documented. Transpiration rate is lower, and water potential is higher, for shaded leaves compared to fully exposed leaves (Williams, 2012). The rate of photosynthesis, particularly of the inner leaves of the canopy, is also lower compared to that of fully exposed leaves (Escalona et al., 2003). The transpiration differences between shaded and fully exposed leaves will become more pronounced as canopy density increases. Determining the fractional contribution of shaded leaves to sap flow was beyond the scope of the study. However, visual observations revealed that the canopies of grapevines used in the study were not excessively dense. Theoretically, a larger fraction of the outer leaf layer of grapevines with horizontal canopies will be exposed to direct sunlight over the course of the day compared to grapevines on vertical trellises. Therefore, less leaf area could transpire due to the limited exposure of the vertical canopies, which caused lower sap flow rates compared to grapevines with horizontal canopies (Fig. 6). 

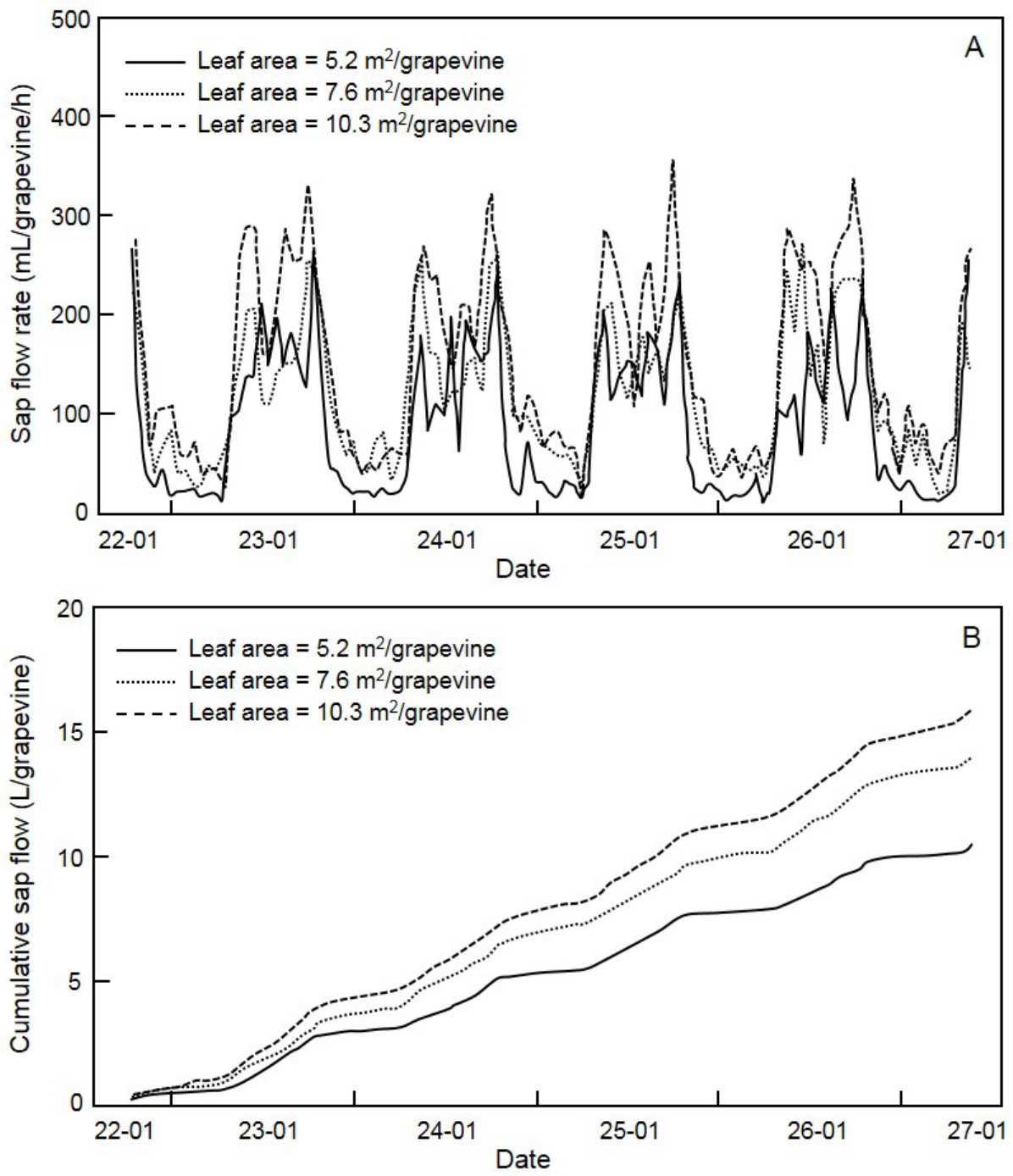

FIGURE 4

Effect of leaf area per grapevine on (A) diurnal sap flow variation and (B) cumulative sap flow in three Sultanina grapevines on a $2.4 \mathrm{~m}$ slanting trellis as measured near Upington during berry ripening from 1995-01-22 to 1995-01-27.

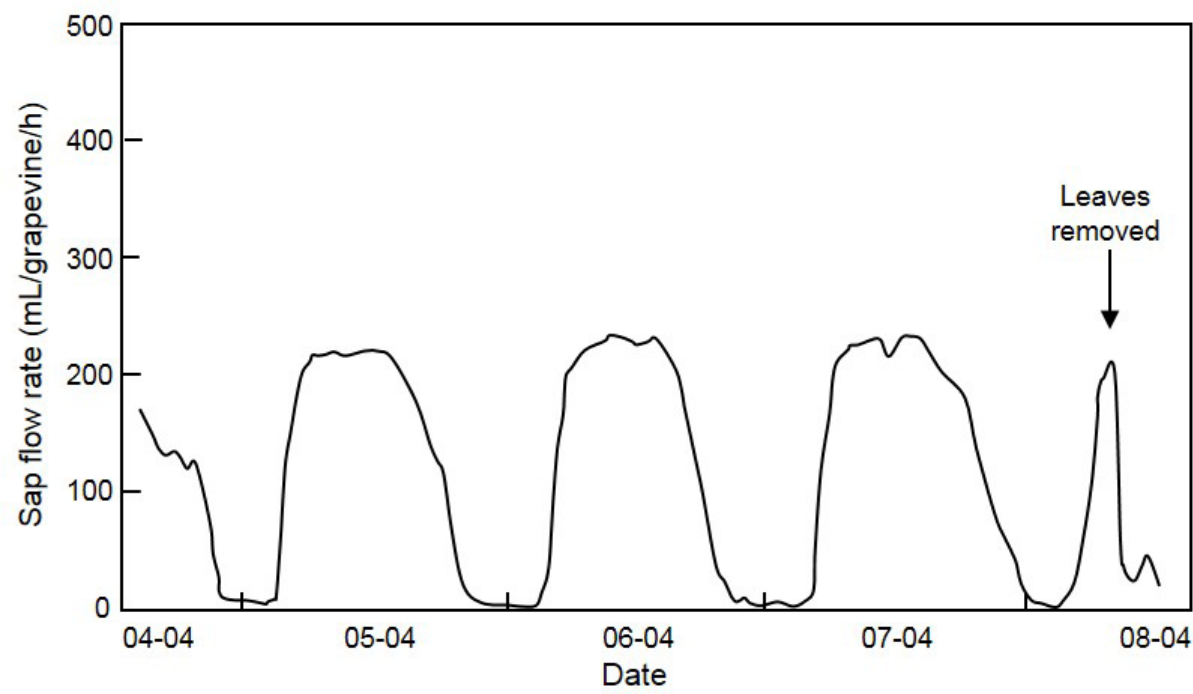

FIGURE 5

Effect of micro-sprinkler irrigation on sap flow rate in an Emerald Riesling grapevine bearing $14.1 \mathrm{~m}^{2}$ leaf area on a Tatura trellis as measured near Robertson shortly after harvest from 1995-04-04 to 1995-04-08. 


\section{Atmospheric conditions}

Since stomatal opening and the transpiration rate of grapevines are controlled by light (Düring, 1976; Rogiers \& Clarke, 2013), sap flow will generally follow diurnal global radiation patterns. Although global radiation followed its normal course on a sunshine day, sap flow in the Barlinka grapevines did not respond concomitantly (Fig. 7). Daytime sap flow appeared to remain constant when global radiation exceeded c. $2 \mathrm{MJ} / \mathrm{m}^{2} / \mathrm{h}$, irrespective of leaf area per grapevine. A similar trend occurred in the case of the Pinot noir grapevines on the vertical trellis in Experiment 4 (Fig. 8). Sap flow in the potted Tempranillo grapevines also showed little increase over the warmest part of the day (Escalona et al., 2002). In fact, sap flow in Weisser Riesling grapevines declined slightly over the warmest part of the day, following a maximum that occurred around 09:00 (Lopes et al., 2004). Previous studies have shown that the transpiration of wellwatered plants, including grapevines, responds non-linearly to radiation (Winkel \& Rambal, 1990 and references therein; Rogiers \& Clarke, 2013). Therefore, it seems that stomatal aperture remained almost constant over the warmest part of the day, which allowed only a certain rate of water loss via transpiration. This trend indicated that, at high levels of soil water availability, i.e. high soil water matric potentials, sap flow rates will not necessarily increase concomitantly. When clouds and light rain prevailed for a short period while Experiment 2 was being carried out, reduced sap flow indicated that partial stomatal closure occurred in the three Barlinka grapevines on the slanting trellis (Fig. 1). The reduction in sap flow caused by adverse atmospheric conditions was in agreement with previous findings (Calo et al., 1999; Escalona et al., 2002).

In contrast to the Barlinka and Merlot grapevines, sap flow in the Sultanina grapevines tended to fluctuate during the day. The sap flow fluctuations in the Sultanina grapevines occurred when global radiation exceeded c. $2 \mathrm{MJ} / \mathrm{m}^{2} / \mathrm{h}$ (Fig. 9). Since global radiation was uninterrupted on the day when the measurements were carried out, the sap flow fluctuations could not have been caused by deviations in atmospheric conditions over the course of the day. This suggests that water deficits in the grapevines induced partial stomatal closure when transpiration losses exceeded water uptake under the conditions of high evaporative demand in the Lower Orange River region (Table 2). However, in the Hex River valley, where the evaporative demand is lower, daytime sap flow fluctuations also occurred in Sunred Seedless grapevines (Myburgh \& Howell, 2006). In the latter case it was concluded that slow water flow to the roots through the sandy soil induced temporary water deficits during the day, and that this caused the fluctuations in sap flow. Therefore, either high evaporative demand, or high levels of soil water depletion, could be the primary cause of daytime sap flow fluctuations. According to Loveys and Düring (1984), abscisic acid accumulation in leaves could also induce midday stomatal closure under semiarid conditions, whereas atmospheric variables such as temperature and vapour pressure deficit are more likely to affect stomatal behaviour later in the day.

Diurnal sap flow per grapevine increased linearly with daily $\mathrm{ET}_{\mathrm{o}}$ under the conditions of the study (Fig. 10). Linear relationships were also reported between daily sap flow and American Class-A pan reference evaporation (Eastham \& Gray, 1998), as well as ET (McClymont et al., 2009). These results clearly indicate that diurnal sap flow was affected by day-to-day changes in evaporative demand, irrespective of leaf area or canopy orientation.

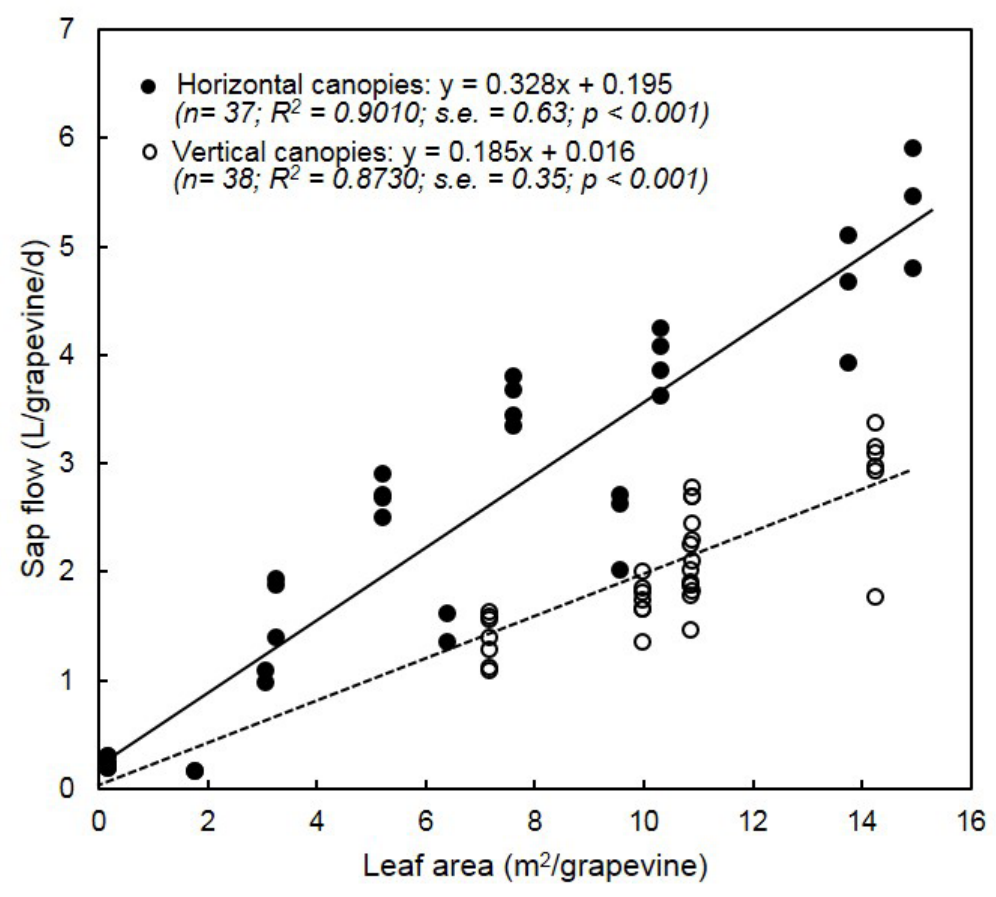

FIGURE 6

Effect of canopy surface orientation on the correlation between diurnal sap flow and leaf area per grapevine. Vertical groups indicate variation in diurnal sap flow in a specific grapevine due to variation in evaporative demand. 


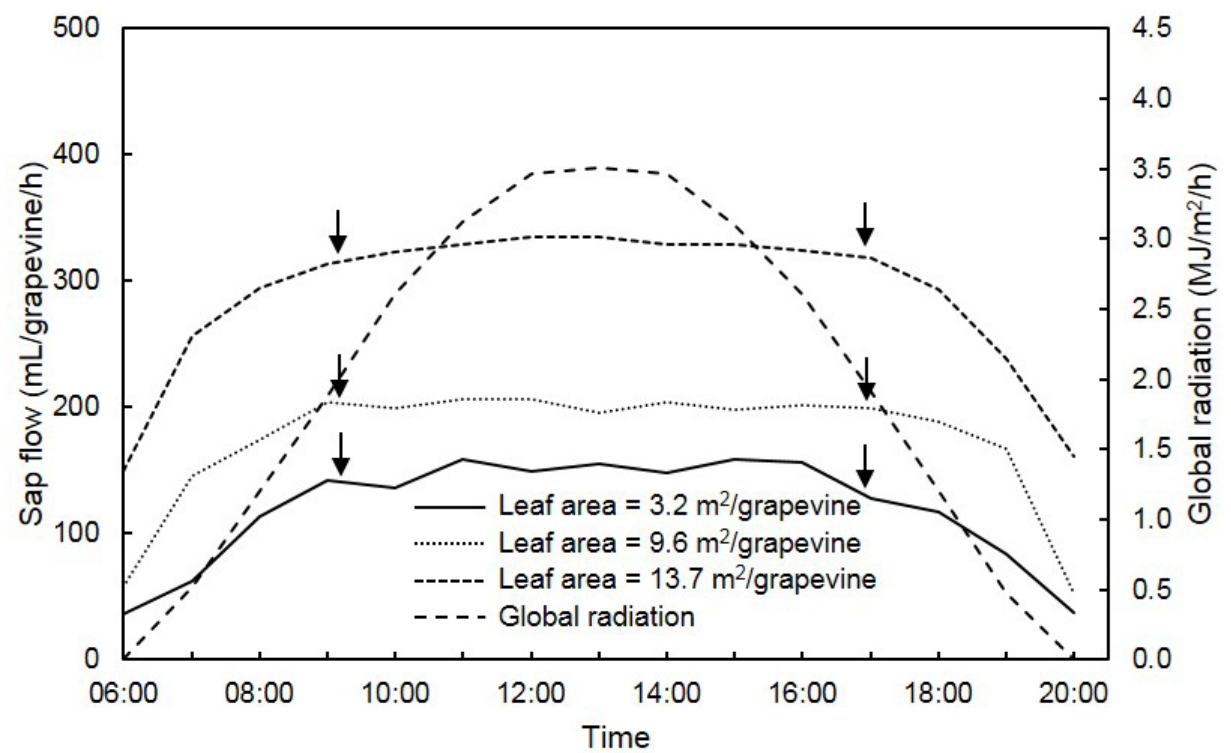

FIGURE 7

Variation in daytime sap flow in three Barlinka grapevines on a $2.4 \mathrm{~m}$ slanting trellis, as well as global radiation as measured near De Doorns on 1994-12-03 . Vertical arrows indicate sap flow when global radiation exceeded or fell below $2 \mathrm{MJ} / \mathrm{m}^{2} / \mathrm{h}$.

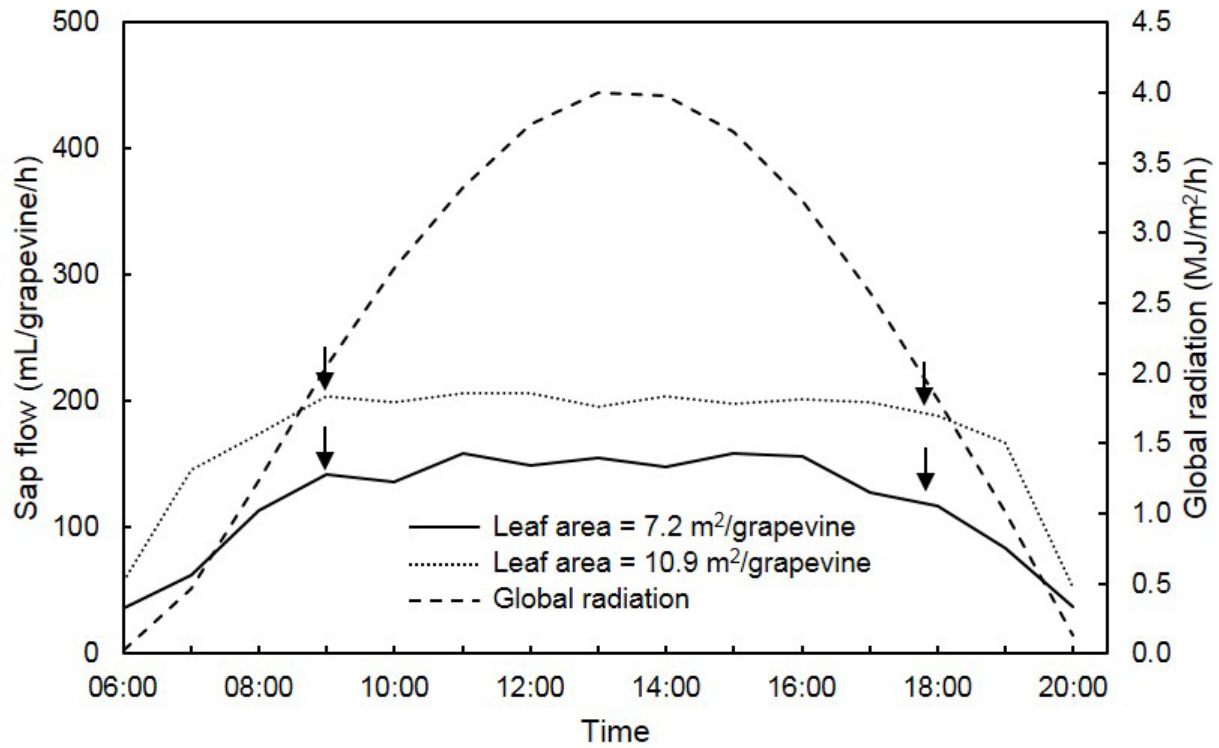

FIGURE 8

Variation in daytime sap flow in two Pinot noir grapevines on a lengthened Perold trellis, as well as global radiation as measured near Stellenbosch on 1995-01-05. Vertical arrows indicate sap flow when global radiation exceeded or fell below $2 \mathrm{MJ} / \mathrm{m}^{2} / \mathrm{h}$.

TABLE 2

Long-term mean monthly reference evapotranspiration $\left(\mathrm{ET}_{\mathrm{o}}\right)$ during the grape-growing season in four South African grapegrowing regions. Data were obtained from the ISCW in Pretoria.

\begin{tabular}{llcccccccc}
\hline \multirow{2}{*}{ Region } & Locality & \multicolumn{9}{c}{ ET $(\mathrm{mm} / \mathrm{d})$} \\
\cline { 3 - 9 } & & Sep & Oct & Nov & Dec & Jan & Feb & Mar & Apr \\
\hline Coastal region & Stellenbosch & 2.58 & 3.84 & 4.07 & 5.44 & 5.66 & 5.12 & 4.26 & 2.82 \\
Breede River Valley & Robertson & 3.41 & 4.41 & 5.13 & 5.49 & 5.87 & 5.40 & 4.07 & 2.47 \\
Hex River Valley & De Doorns & 3.48 & 4.11 & 5.24 & 5.40 & 5.91 & 5.54 & 4.38 & 2.46 \\
Lower Orange River & Upington & 4.26 & 5.01 & 6.19 & 6.77 & 6.42 & 5.78 & 4.88 & 3.59 \\
\hline
\end{tabular}




\section{Basal crop coefficients}

The $\mathrm{K}_{\mathrm{cb}}$ values increased with increasing leaf area (Fig. 11). As expected, $\mathrm{K}_{\mathrm{cb}}$ for horizontally orientated canopies was higher compared to that of vertically orientated ones, for reasons as discussed above. The $\mathrm{K}_{\mathrm{cb}}$ values were substantially lower compared to the values proposed for well-watered, non-stressed grapevines (Allen et al., 1998). Since the grapevines were not irrigated while sap flow measurements were being carried out, limited water constraints could have reduced stomatal aperture. This was probably the reason why daily sap flow was generally lower compared to the values reported for well-watered, non-stressed grapevines (McClymont et al., 2009; Poblete-Echeverría et al., 2012; Pearsall et al., 2014). Therefore, slower water uptake could have reduced transpiration, causing the low $\mathrm{K}_{\mathrm{cb}}$ values. It was previously reported that $\mathrm{K}_{\mathrm{c}}$ for non-irrigated vineyards can be as low as 0.2 (Oliver \& Sene, 1992). The $\mathrm{K}_{\mathrm{c}}$ values for nonirrigated grapevines near Stellenbosch were even less than

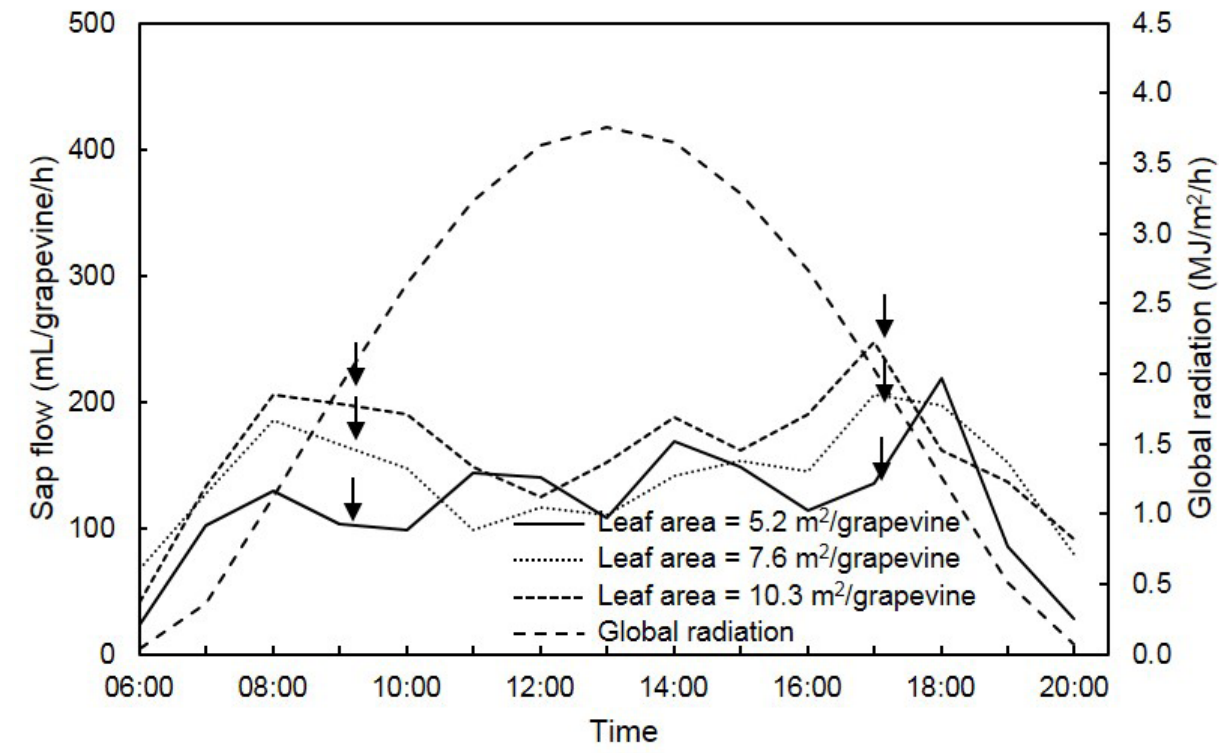

FIGURE 9

Variation in daytime sap flow in three Sultanina grapevines on a $2.4 \mathrm{~m}$ slanting trellis, as well as global radiation as measured near Upington on 1995-01-25. Vertical arrows indicate sap flow when global radiation exceeded or fell below $2 \mathrm{MJ} / \mathrm{m}^{2} / \mathrm{h}$.

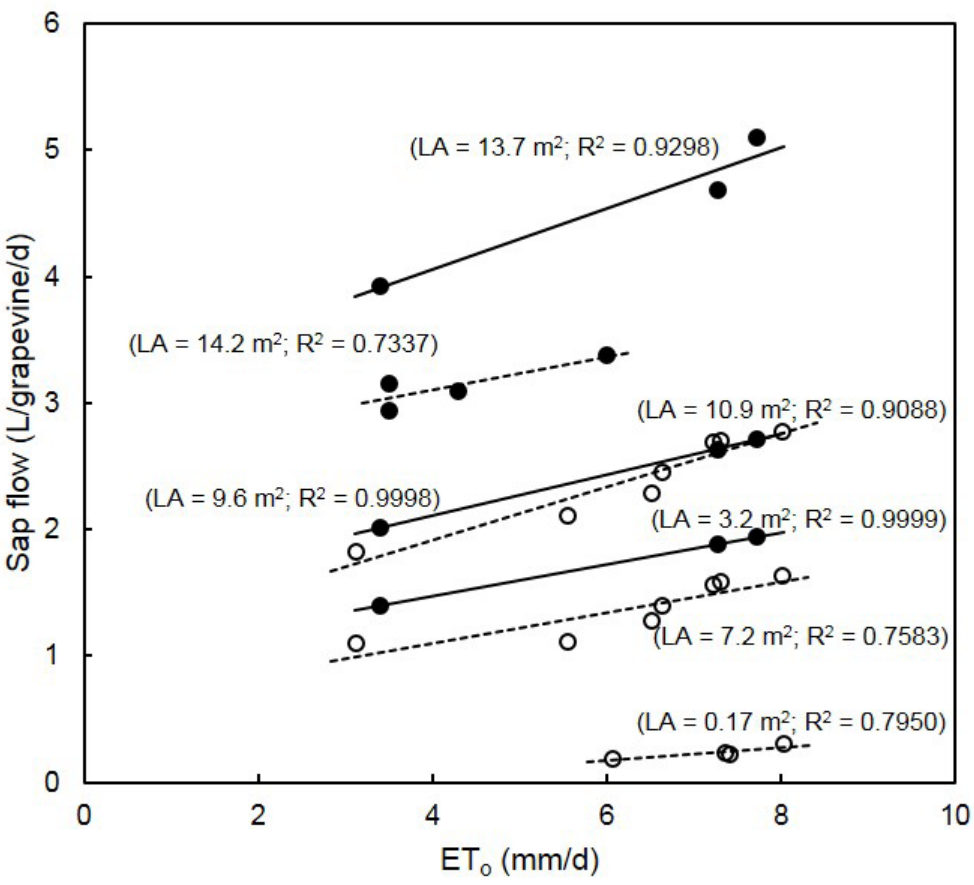

FIGURE 10

Correlation between diurnal sap flow and reference evapotranspiration (ET $)$ for seven grapevines differing in leaf area (LA). Solid and open circles indicate grapevines on horizontal and vertical trellises respectively. Values in brackets indicate leaf area per grapevine and the coefficient of determination. 


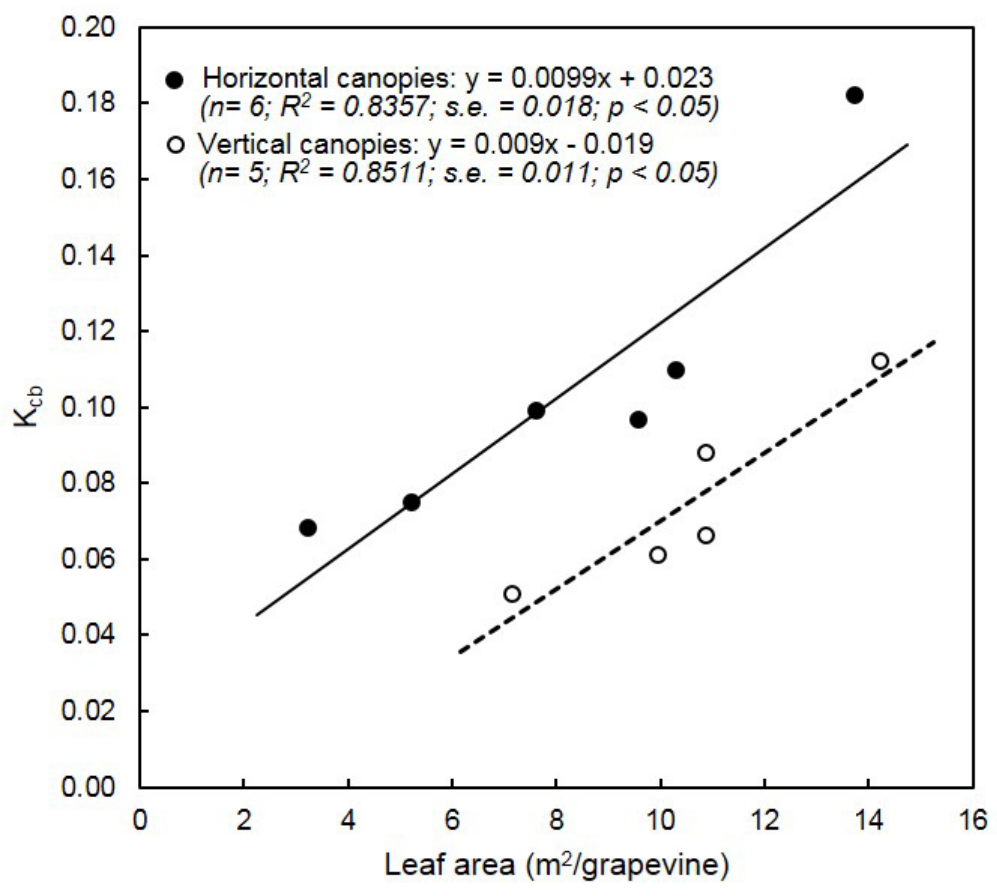

FIGURE 11

Effect of canopy surface orientation on the correlation between basal crop coefficient $\left(\mathrm{K}_{\mathrm{cb}}\right)$ and leaf area per grapevine.

0.2 during berry ripening (Laker, 2004). Midday $\Psi_{L}$ in these grapevines was higher than -1.4 MPa (Laker, 2004), which indicated that they experienced moderate water constraints (Myburgh, 2011a and references therein).

Since the daily $\mathrm{E}_{\mathrm{s}}$ from vineyard soils becomes minimal two to three weeks after rainfall or irrigation (Myburgh, 2015), it can be assumed that the magnitude of $\mathrm{K}_{\mathrm{c}}$ is primarily determined by transpiration under rain-fed conditions. Under such conditions, $\mathrm{K}_{\mathrm{cb}}$ could be almost equal to $\mathrm{K}_{\mathrm{c}}$ without detrimental effects on grapevine physiological functioning. Since high evaporation losses occur if irrigation is applied frequently (Myburgh, 2015), $\mathrm{K}$ may exceed $\mathrm{K}_{\mathrm{cb}}$ in the dual-crop coefficient approach. Growing wellwatered, non-stressed grapevines in which the $\mathrm{K}_{\mathrm{cb}}$ values recommended by Allen et al. (1998) would apply is not always a sustainable option in South Africa. In addition to low rainfall in the grape-growing regions, irrigation water resources are limited in many cases. Therefore, commercial vineyards experience moderate to strong water constraints that will result in low $\mathrm{K}_{\mathrm{cb}}$ values. Furthermore, it was shown that table grapes require moderate water constraints in order to improve quality, particularly berry colour, under South African conditions (Myburgh, 1996; Myburgh \& Howell, 2007b; Howell et al., 2013). Likewise, grapes grown for the production of red wine should experience at least moderate water constraints to improve wine quality (Lategan, 2011; Myburgh, 2011b). The foregoing suggests that $\mathrm{K}_{\mathrm{cb}}$ could be lower than 0.2 for vineyards experiencing water deficits. However, higher $\mathrm{K}_{\mathrm{cb}}$ values will be applicable to the dried and table grape vineyards in the sandy and weathered granitegneiss soils of the Lower Orange River region (Myburgh, 2003b; Myburgh, 2012).

\section{Estimating diurnal transpiration}

The close relationship between diurnal sap flow and leaf area per grapevine, as well as the sharp reduction in sap flow immediately after leaf removal, shows that sap flow is predominantly a function of whole-plant transpiration. The close relationship between sap flow and leaf area per grapevine is in agreement with earlier findings (Zhang et al., 2011). Therefore, transpiration could be assumed to be equal to sap flow for the modelling objective of the study. The results of the different experiments showed that the magnitude of daily sap flow was primarily determined by leaf area per grapevine, canopy surface orientation and atmospheric conditions as quantified by means of $\mathrm{ET}_{\mathrm{o}}$. Consequently, variation in daily sap flow could to a large extent be explained if these variables were used in the following multiple linear regression model:

$\mathrm{T}=\mathrm{m}_{1} \mathrm{LA}+\mathrm{m}_{2} \mathrm{ET}_{\mathrm{o}}+\mathrm{c}$

where $\mathrm{T}$ is daily grapevine transpiration (L/grapevine/d), $\mathrm{m}_{1}$ is the coefficient of leaf area per grapevine (LA) in $\mathrm{m}^{2}, \mathrm{~m}_{2}$ is the coefficient of reference evapotranspiration $\left(\mathrm{ET}_{\mathrm{o}}\right)$ in $\mathrm{mm} / \mathrm{d}$ and $\mathrm{c}$ is a constant. The coefficients and constants for the horizontal and vertical canopy models respectively are presented in Table 3.

Since most of the grapevines used to develop the models were irrigated during the growing season, it must be assumed that low to moderate water constraints occurred. Therefore, the application of the models would be limited to conditions where water constraints would not have any negative effects on grapevine physiological functioning. However, this might not be a serious shortcoming in irrigated vineyards, since the purpose of irrigation is to avoid excessive water constraints. Where grapevines are grown 
TABLE 3

Coefficients and constants for multiple linear regression models for estimation of daily transpiration of grapevines on horizontal and vertical trellises respectively, as well as the number of observations (n), coefficient of determination $\left(\mathrm{R}^{2}\right)$, standard error of estimation (s.e.) and level of significance (p).

\begin{tabular}{|c|c|c|c|c|c|c|c|}
\hline \multirow{2}{*}{$\begin{array}{l}\text { Canopy } \\
\text { orientation }\end{array}$} & \multicolumn{2}{|c|}{ Coefficients } & \multirow{2}{*}{ - Constant } & \multirow{2}{*}{$n$} & \multirow{2}{*}{$R^{2}$} & \multirow[b]{2}{*}{ s.e. } & \multirow[b]{2}{*}{$p$} \\
\hline & Leaf area $\left(\mathrm{m}_{1}\right)$ & $\operatorname{ET}_{\mathrm{o}}\left(\mathrm{m}_{2}\right)$ & & & & & \\
\hline Horizontal & 0.331 & 0.185 & -1.14 & 30 & 0.9226 & 0.48 & $<0.001$ \\
\hline Vertical & 0.199 & 0.065 & -0.4 & 38 & 0.8583 & 0.31 & $<0.001$ \\
\hline
\end{tabular}

on dry land, i.e. rain-fed, excessive water deficits are more likely to reduce transpiration and, consequently, to reduce model accuracy. Modelling the transpiration of severely stressed, non-irrigated grapevines was beyond the scope of the study. The transpiration models for vineyards with horizontal and vertically orientated canopies respectively were not validated against independent whole-plant sap flow measurements. Instead, the transpiration models were combined with a soil evaporation model for the estimation of ET for irrigation scheduling. When the $\mathrm{ET}_{\mathrm{c}}$ model was validated against eight independent datasets where $\mathrm{ET}_{c}$ was measured in-field, close agreement was obtained between actual and estimated ET (Myburgh, 1998). This confirmed that the grapevine transpiration models were reasonably accurate under different atmospheric, soil and viticultural conditions.

\section{CONCLUSIONS}

Assuming that transpiration almost equalled sap flow, whole-grapevine transpiration was closely related to total leaf area per grapevine. However, due to differences in exposure to radiation, and therefore light interception, grapevines with horizontal canopies transpired more than those with vertical canopies. Furthermore, there was a linear relationship between whole-grapevine transpiration and evaporative demand. Based on the foregoing relationships, a simple model was established for estimating wholeplant transpiration by means of multiple linear regression. Although this model should be considered as a first approach, it can be recommended for use in combination with evaporation models for estimating the $\mathrm{ET}_{\mathrm{c}}$ of vineyards that are not subjected to severe water deficits. However, research must be continued to improve model accuracy with respect to possible effects of cultivar differences, foliage management, transpiration efficiency of ageing leaves, row direction and level of soil water depletion. The latter aspect is of particular importance where irrigation must be managed to achieve specific grape and wine quality objectives.

\section{LITERATURE CITED}

Allen, R.G., Pereira, L.S., Raes, D. \& Smith, M., 1998. Crop evapotranspiration: Guidelines for computing crop water requirements. FAO Irrigation and Drainage Paper 56, Rome.

Avenant, J.H., 1990. Trellising systems: Single slanting, factory roof and Trentina (Tyrolean). Farming in S. Afr., VORI 276/1990, ARC InfruitecNietvoorbij, Private Bag X5026, Stellenbosch 7599, South Africa.

Baker, J.M. \& Van Bavel, C.H.M., 1987. Measurement of mass flow of water in stems of herbaceous plants. Plant Cell Environ. 10, 777-782.
Beis, A. \& Patakas, A., 2010. Differences in stomatal responses and root to shoot signaling between two grapevine varieties subjected to drought. Funct. Plant. Biol. 37, 139-146.

Booysen, J.H., Steenkamp, J. \& Archer, E., 1992. Names of vertical trellising systems (with abbreviations). Wynboer, September, 15.

Braun, P. \& Schmid, J., 1999. Sap flow measurements in grapevines (Vitis vinifera L.) 2. Granier measurements. Plant Soil 215, 47-55.

Calo, A., Giorgessi, F., Sansone, L., Tomasi, D. \& Zerbi, G., 1999. Recherches sur le rapport entre le flux de seve, la transpiration et la vigueur dans la vigne selon le mode de conduit par. Vitis 38, 7-13.

De Lorenzi, F. \& Rana, G., 2000. Sap flow transpiration measurements in a table grape vineyard growing in southern Italy. In: Ferreira, M.I. \& Jones, H. (eds). Proc. 3rd Int. Symp. on Irrigation of Hort. Crops, ISHS, Acta Hort. 537, 69-75.

De Souza, C.R., Maroco, J.P., Dos Santos, T.P., Rodrigues, M.L., Lopes, C.M., Pereira, J.S. \& Chaves, M.M., 2003. Partial rootzone drying: Regulation of stomatal aperture and carbon assimilation in field-grown grapevines (Vitis vinifera cv. Moscatel). Funct. Plant Biol. 30, 653-662.

Düring, H., 1976. Untersuchungen zur Umweltabhängigket der Stomatären Transpiration bei Reben. I. Beleuchtungstärke and Luffeuchtigkeit. Vitis 15, $82-87$.

Eastham, J. \& Gray, S.A., 1998. A preliminary evaluation of the suitability of sap flow sensors for use in scheduling vineyard irrigation. Am. J. Enol. Vitic. 49, 171-176.

Escalona, J.M., Flexas, J., Bota, J. \& Medrano, H., 2003. Distribution of leaf photosynthesis and transpiration within grapevine canopies under different drought conditions. Vitis 42, 57-64.

Escalona, L., Flexas, J. \& Medrano, H., 2000. Comparison of heat balance and gas exchange methods to measure transpiration in irrigated and water stressed grapevines. In: Bravdo, B.A. (ed.). Proc. 5th Int. Symp. on Grapevine Physiol., ISHS. Acta Hort. 526, 145-156.

Escalona, J., Flexas, J. \& Medrano, H., 2002. Drought effects on water flow, photosynthesis and growth of potted grapevines. Vitis 41, 75-62.

Escalona, J.M., Fuentes, S., Tomása, M., Martorella, S., Flexas, J. \& Medrano, H., 2013. Responses of leaf night transpiration to drought stress in Vitis vinifera L. Agr. Water Manage. 118, 50-58.

Escalona, J.M. \& Ribas-Carbó, 2010. Methodologies for the measurement of water flow in grapevines. In: Delrot, S., Medrano, H., Or, E., Bavaresco, L. \& Grando, S. (eds). Methodologies and Results in Grapevine Research. Springer, London, pp 71-86.

Fernández, J.E., Green, S.R., Caspari, H.W., Diaz-Espejo, A. \& Cuevas, M.V., 2008. The use of sap flow measurements for scheduling irrigation in olive, apple and Asian pear trees and in grapevines. Plant Soil 305, 91-104.

Fourie, A., 1989. The effect of four soil water regimes on the performance of Barlinka table grapes in the Hex River Valley. Thesis, Stellenbosch University, Private Bag X1, 7602 Matieland, South Africa. 
Fuentes, S., Collins, M., Rogers, G., Acevedo, C. \& Conroy, J.P., 2009. Nocturnal heat-pulse sap flow as a sensitive system to assess drought effects on grapevines: An irrigation scheduling application? In: Fernández, E. \& Diaz-Aspejo, A. (eds). Proc. 7th Int. Workshop on Sap flow, ISHS. Acta Hort. 846, 167-175.

Fuentes, S., De Bei, R., Collins, M.J., Escalona, J.M., Medrano, H. \& Tyerman, S., 2014. Night-time responses to water supply in grapevines (Vitis vinifera L.) under deficit irrigation and partial root-zone drying. Agr. Water Manage. 138, 1-9.

Ginestar, C., Eastham, J., Gray, S. \& Iland, P., 1998. Use of sap-flow sensors to schedule vineyard irrigation. I. Effects of post-veraison water deficits on water relations, vine growth and yield of Shiraz grapevines. Am. J. Enol. Vitic. 49, 413-420.

Green, G.C., 1985. Estimated irrigation requirements of crops in South Africa. Part 1. Memoirs on the Agricultural Resources of South Africa No. 2. Dept. Agriculture and Water Supply, Pretoria.

Howell, C.L., Myburgh, P.A. \& Conradie, W.J., 2013. Comparison of three different fertigation strategies for drip irrigated table grapes - Part III. Growth, yield and quality. S. Afr. J. Enol. Vitic. 34, 21-29.

Laker, M.S., 2004. The effect of atmospheric and soil conditions on the grapevine water status. Thesis, Stellenbosch University, Private Bag X1, 7602 Matieland (Stellenbosch), South Africa.

Lascano, R.J., Baumhardt, R.L. \& Lipe, W.N., 1992. Measurement of water flow in young grapevines using the stem heat balance method. Am. J. Enol. Vitic. 43, 159-165.

Lategan, E.L., 2011. Determining of optimum irrigation schedules for drip irrigated Shiraz vineyards in the Breede River valley. Thesis, Stellenbosch University, Private Bag X1, 7602 Matieland (Stellenbosch), South Africa.

Le Roux, E.G., 1974. A climate classification for the South Western Cape viticultural areas (in Afrikaans). Thesis, Stellenbosch University, Private Bag X1, 7602 Matieland (Stellenbosch), South Africa.

Lopes, C., Monteiro, A., Rückert, F.E., Gruber, B., Steinberg, B. \& Schultz, H.R., 2004. Transpiration of grapevines and co-habitating cover crop and weed species in a vineyard. A "snapshot" at diurnal trends. Vitis 43, 111117.

Loveys, B.R. \& Düring, H., 1984. Diurnal changes in water relations and abscisic acid in field-grown Vitis vinifera cultivars II. Abscisic acid changes under semi-arid conditions. New Phytol. 97, 37-47.

McClymont, L., Goodwin, I. Whitfield, D.M. \& Green, S., 2009. The relationship between grapevine sap flow, $\mathrm{ET}_{\mathrm{o}}$ and effective area of shade. In: Fernández, E. \& Diaz-Espejo, A. (eds). Proc. 7th ISHS Int. Workshop on Sap Flow, Acta Hort. 846, 185-192.

Myburgh, P.A., 1996. Response of Vitis vinifera L. cv. Barlinka/Ramsey to soil water depletion levels with particular reference to trunk growth parameters. S. Afr. J. Enol. Vitic. 17, 3-14.

Myburgh, P.A., 1998. Water consumption of South African vineyards: A modelling approach based on the quantified combined effects of selected viticultural, soil and meteorological parameters. Dissertation, Stellenbosch University, Private Bag X1, 7602 Matieland (Stellenbosch), South Africa.

Myburgh, P.A., 2003a. Possible flood irrigation technologies to reduce water use of Sultanina grapevines in a hot, arid climate. S. Afr. J. Plant Soil 20, 180-187.

Myburgh, P.A., 2003b. Responses of Vitis vinifera L. cv. Sultanina to level of soil water depletion under semi-arid conditions. S. Afr. J. Enol. Vitic. 24, 16-24.

Myburgh, P.A., 2011a. Response of Vitis vinifera L. $c v$. Merlot to low frequency drip irrigation and partial root zone drying in the Western Cape Coastal region - Part I. Soil and plant water status. S. Afr. J. Enol. Vitic. 32, 89-103.
Myburgh, P.A., 2011b. Response of Vitis vinifera L. $c v$. Merlot to low frequency drip irrigation and partial root zone drying in the Western Cape Coastal region - Part II. Vegetative growth, yield and quality. S. Afr. J. Enol. Vitic., 32, 104-116.

Myburgh, P.A., 2012. Comparing irrigation systems and strategies for table grapes in the weathered granite-gneiss soils of the Lower Orange River region. S. Afr. J. Enol. Vitic. 33, 184-197.

Myburgh, P.A., 2013. Effect of shallow tillage and straw mulching on soil water conservation and grapevine response. S. Afr. J. Plant Soil 30, 219225 .

Myburgh, P.A., 2015. A lysimeter study to determine input values for a simple parametric soil evaporation model for vineyards. S. Afr. J. Plant Soil $32,1-8$.

Myburgh, P.A. \& Coetzee, F., 2004. Apparatus for non-destructive measurement of grapevine trunk cross-sectional area. S. Afr. J. Plant Soil 21, 67-69.

Myburgh, P.A. \& Howell, C.L., 2006. Water relations of Vitis vinifera L. cv. Sunred Seedless in response to soil water depletion before harvest. S. Afr. J. Enol. Vitic. 27, 196-201.

Myburgh, P.A. \& Howell, C.L., 2007a. Evapotranspiration of Vitis vinifera L. cvs. Sunred Seedless and Muscat Supreme in response to soil water depletion and irrigation cutoff during berry ripening. S. Afr. J. Plant Soil 24, 209-213.

Myburgh, P.A. \& Howell, C.L., 2007b. Responses of Sunred Seedless and Muscat Supreme to irrigation during berry ripening II - Quality aspects. S. Afr. Fruit J., Feb/March, 28-32.

Myburgh, P.A., Van Zyl, J.L. \& Conradie, W.J., 1996. Effect of soil depth on growth and water consumption of young Vitis vinifera L. $c v$. Pinot noir. S. Afr. J. Enol. Vitic. 17, 53-62.

Oliver, H.R. \& Sene, K.J., 1992. Energy and water balances of developing vines. Agr. Forest Meteorol. 61, 167-185.

Patakas, A., Noitsakis, B. \& Chouzouric, A., 2005. Optimization of irrigation water use in grapevines using the relationship between transpiration and plant water status. Agr. Ecosyst. Environ. 106, 253-259.

Pearsall, K.R., Williams, L.E., Castorani, S., Bleby, T.M. \& McElrone, A.J., 2014. Evaluating the potential of a novel dual heat-pulse sensor to measure volumetric water use in grapevines under a range of flow conditions. Funct. Plant Biol. 41, 874-883.

Poblete-Echeverría, C.A. \& Ortega-Farias, S.O., 2013. Evaluation of single and dual crop coefficients over a drip-irrigated Merlot vineyard (Vitis vinifera L.) using combined measurements of sap flow sensors and an eddy covariance system. Aust. J. Grape Wine Res. 19, 249-260.

Poblete-Echeverría, C., Ortega-Farias, S., Zuñiga, M. \& Fuentes, S., 2012. Evaluation of compensated heat-pulse velocity method to determine vine transpiration using combined measurements of eddy covariance system and microlysimeters. Agr. Water Manage. 109, 11-19.

Rogiers, S.Y. \& Clarke, S.J., 2013. Nocturnal and daytime stomatal conductance respond to root-zone temperature in 'Shiraz' grapevines. Ann. Bot. 111, 433-444.

Rogiers, S.Y., Greer, D.H., Hatfield, J.M., Hutton, R.J., Clarke, S.J., Hutchinson, P.A. \& Somers, A., 2012. Stomatal response of an anisohydric grapevine cultivar to evaporative demand, available soil moisture and abscisic acid. Tree Physiol. 32, 249-261.

Schmid, J., 1997. Xylemflussmessungen an Reben. Geisenheimer Berichte, Band 33, Gesellschaft zur Förderung der Forschungsanstalt, Geisenheim.

Scholander, P.F., Hammel, H.T., Bradstreet, E.D. \& Hemmingsen, E.A., 1965. Sap flow in vascular plants. Science 148, 339-346. 
Soil Classification Work Group, 1991. Soil classification - A taxonomic system for South Africa. Memoirs on natural resources of South Africa no. 15. Dept. Agric. Developm., Private Bag X116, 0001 Pretoria, Republic of South Africa.

Swanson, R.H. \& Whitfield, D.W.A., 1981. A numerical analysis of heat pulse velocity theory and practice. J. Exp. Bot. 32, 221-239.

Van den Ende, B., 1994. The Tatura trellis - A system of growing grapevines for early and high production. Am. J. Enol. Vitic. 35, 82-87.

Van Zyl, J.L., 1987. Diurnal variation in grapevine water stress as a function of changing soil water status and meteorological conditions. S. Afr. J. Enol. Vitic. 8, 45-52.

Williams, L.E., 2012. Leaf water potentials of sunlit and/or shaded grapevine leaves are sensitive alternatives to stem water potential. J. Int Sci. Vigne Vin 46, 207-219.
Williams, L.E., Baeza, P. \& Vaughn, P., 2011. Midday measurements of leaf water potential and stomatal conductance are highly correlated with daily water use of Thompson Seedless grapevines. Irrigation Sci. 30, 201-212.

Winkel, T. \& Rambal, S., 1990. Stomatal conductance of some grapevines growing in the field under a Mediterranean environment. Agri. Forest Meteorol. 51, 107-121.

Winkler, A.J., 1962. General viticulture. University of California Press, Los Angeles.

Zhang, Y., Kang, S., Ward, E.J., Ding, R., Zhang, X. \& Zheng, R., 2011. Evapotranspiration components determined by sap flow and microlysimetry techniques of a vineyard in northwest China: Dynamics and influential factors. Agr. Water Manage. 98, 1207-1214. 